\title{
SUBMICROSECOND ATMOSPHERIC ELECTRIC DISCHARGE FROM THE NON-UNIFORM ELECTRODE (TIP) TOWARDS THE PLANE ELECTRODE
}

\author{
Vasily Y. Kozhevnikov ${ }^{\mathrm{a}}$, Andrey V. Kozyrev ${ }^{\mathrm{b}}$, \\ Aleksandr O. Kokovin ${ }^{c}$, Vladislav S. Igumnov ${ }^{\mathrm{d}}$ \\ ${ }^{a}$ Institute of High Current Electronics, Department of Theoretical \\ Physics, Tomsk, Russian Federation, \\ e-mail: Vasily.Y.Kozhevnikov@ieee.org, \\ ORCID iD: (iottp://orcid.org/0000-0001-7499-0578 \\ ${ }^{\mathrm{b}}$ Institute of High Current Electronics, Department of Theoretical \\ Physics, Tomsk, Russian Federation, \\ e-mail:kozyrev@to.hcei.tsc.ru, \\ ORCID iD: (i)https://orcid.org/0000-0002-7078-7991 \\ ${ }^{c}$ Institute of High Current Electronics, Department of Theoretical \\ Physics, Tomsk, Russian Federation, \\ e-mail: alexander.kokovin.desch@gmail.com, \\ ORCID iD: (Dhttp://orcid.org/0000-0003-2068-7674 \\ ${ }^{d}$ National Research Tomsk Polytechnic University, Laboratory N 46 \\ Tomsk, Russian Federation, \\ e-mail: vladislavigumnov@yahoo.com, \\ ORCID iD: (Dhttp://orcid.org/0000-0002-3847-5322
}

DOI: 10.5937/vojtehg67-20796; https://doi.org/10.5937/vojtehg67-20796

FIELD: Plasma Physics

ARTICLE TYPE: Original scientific paper ARTICLE LANGUAGE: English

\section{Abstract:}

This paper deals with the results of a numerical simulation of the fast atmospheric pressure discharge in a strongly non-uniform configuration of a tip-to-plane diode filled with a nitrogen and oxygen mixture. The simulation is based on the advanced hydrodynamic plasma discharge accounting also gas photoionization. It was shown that, in the absence of photoionization, discharge develops similarly to the case with photoionization, except the case of reversed voltage polarity. The theoretical results correspond to the existing experimental data for the spatial discharge structure and the current/voltage discharge characteristics.

Key words: plasma, numerical simulation, atmospheric discharges. 


\section{Introduction}

Various gas-filled diodes are widely used in modern electro-technical devices. The tip-to-plane electrodes system represents probably the most common design of a gas diode unit with a strongly non-uniform configuration of an electric field. Namely, they are used as spark-gap high-voltage switches (Shaefer et al, 1990) as well as the main component of technological devices for the discharge plasma surface treatment (Akishev et al, 2001). Therefore, major theoretical problems of discharge development in such a system are intensively investigated by using various theoretical simulation approaches (Eichwald et al, 2011).

The discharges in gas-filled diodes are attractive due to the nontrivial switching characteristics and the low-temperature plasma parameters. Among the switching parameters, the breakdown formation time and the corresponding voltage amplitude are the most important. The plasma parameters, e.g. its spatial structure or its plasma-chemical composition are also of great importance, especially w.r.t. timedependent studies. While the switching characteristics can be easily measured experimentally, the measurement of plasma parameters is much more complicated. That is the main reason to perform a theoretical simulation of gas discharge.

At present, we have a rather extensive base of experimental studies of this type of discharge, including those performed with picosecond and subnanosecond time resolutions, as well as with time synchronization of measured signals. As part of the series of experimental studies done by groups of Russian and Chinese researchers (Shao et al, 2013), a comparison can be made with the results of actual theoretical studies.

In this paper, we use a two-moment "liquid" discharge plasma model (Gogolides \& Sawin, 1992) implemented in the Plasma module of COMSOL Multiphysics 5.2 software. It allows modeling the timedependent discharge propagation from the metal non-uniform electrode (tip) towards the second electrode (plane) accounting for all necessary plasma-chemical reactions. The main aim here is to simulate nanosecond gas discharge and accurately obtain the spatial discharge structure evolution. The introduction is an introductory part of the article.

\section{Experimental setup}

The experimental setup is represented in Figure 1. The triggering pulse from 1 provides a signal that the voltage pulse generator 2 transforms into a negative polarity voltage pulse with the amplitude values in the range of $U_{0} \approx 27-30 \mathrm{kV}$ with the rise time $t_{f} \approx 200 \mathrm{~ns}$. The 
cathode here is a thin needle with a diameter of $0.4 \mathrm{~mm}$ having the tip curvature radius of $0.1 \mathrm{~mm}$ (medical syringe needle), while the anode is a simple plane electrode made of aluminum foil. The distance between the electrodes is equal to $d=9 \mathrm{~mm}$. The nitrogen at $1 \mathrm{~atm}$ pressure with small ( $2 \%$ ) oxygen admixture is used as the operating gas.

An ICCD camera was used to obtain a sequence of instant images of the discharge dynamics (depicted in Figure 2). The images from an ICCD camera are an integral picture of the glow of non-stationary discharge, which, to a certain extent, can be compared with the distribution of the discharge plasma at a given point in time. Based on this comparison of experimental and theoretical data can be done in the present work.

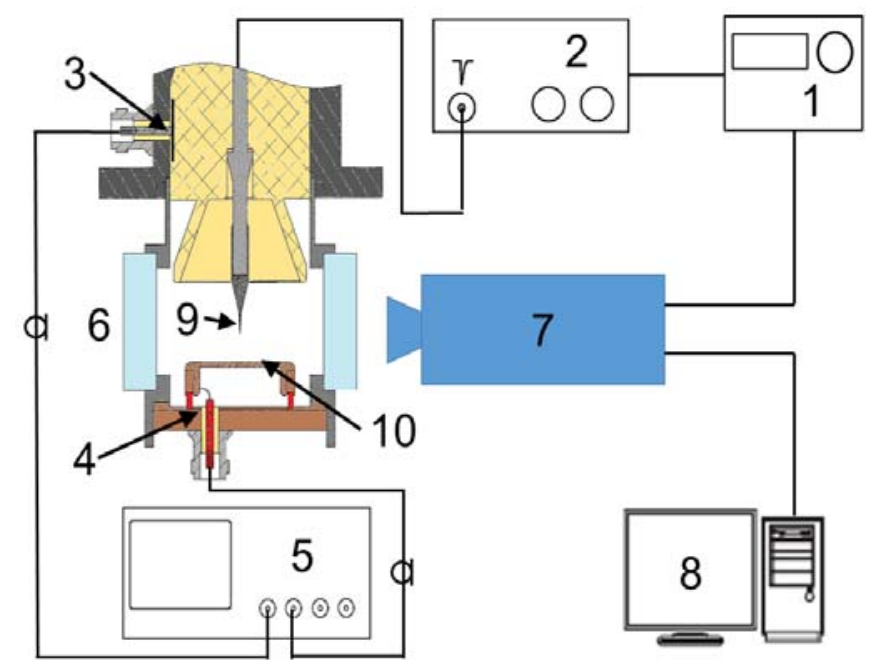

Figure 1 - The experimental setup: 1 - triggering pulse generator, 2 - pulsed voltage source, 3 - capacitive voltage divider, 4 - current shunt resistor, 5 - storage oscilloscope, 6 - output window, 7 - ICCD camera, 8-personal computer, 9 - metal tip cathode, 10 - plane anode electrode

Puc. 1 - Схема эксперимента: 1 - запускающий генератор, 2 - импульсный источник напряжения, 3 - емкостный делитель напряжения, 4 - токовый шунт, 5

- цифровой запоминающий осциллограф, 6 - выходное окно, 7 - скоростная камера, 8 - компьютер, 9 - острийный катод, 10 - плоский анод

Слика 1 - Поставка експеримента: 1 - генератор окидног импулса, 2 - пулсни извор напона, 3 - капацитивни разделник напона, 4 - шант отпорник, 5 меморијски осцилоскоп, 6 - заштитни прозор, 7 - камера ИЦЦД, 8 - лични рачунар, 9 - катода - метални врх, 10 - анода - обична плочаста електрод 


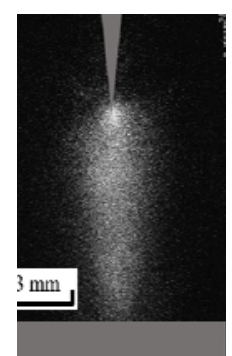

a) $71-74 \mathrm{~ns}$

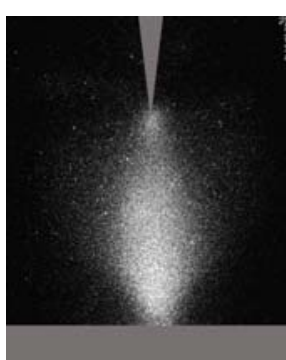

b) $74-77 n s$

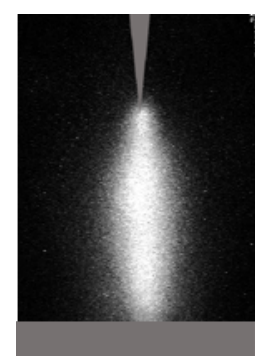

c) $77-80 \mathrm{~ns}$

Figure 2 - Instant photographs from the ICCD-camera (grey areas depict the electrodes) Puc. 2 - Мгновенные фотографрии свечения, полученные скоростной камерой (области, отмеченные серым цветом обозначают электроды) Слика 2 - Инстант фотографије добијене камером ИЦЦД (сиве зоне представљају електроде)

\section{Theoretical model}

For the simplicity reasons, a real three-dimensional diode in the model is substituted by a two-dimensional axisymmetric structure (Figure 3).

The gas discharge model is based on the two-moment "liquid" model where the movement of charged particles is covered by the drift-diffusion approximation (Gogolides \& Sawin, 1992). Since the discharge characteristic time is short, the model implements only three important plasma-chemical reactions: electron impact ionization $\mathrm{e}+\mathrm{N}_{2} \rightarrow 2 \mathrm{e}+\mathrm{N}_{2}{ }^{+}$, molecular nitrogen dissociation $\mathrm{e}+\mathrm{N}_{2} \rightarrow \mathrm{e}+2 \mathrm{~N}$ and photoionization $\mathrm{h} v+\mathrm{N}_{2} \rightarrow \mathrm{e}+\mathrm{N}_{2}^{+}$.

The photoionization model we implement is based on the assumption (Kulikovsky, 1995) that the major contribution to the photoionization rate is produced by the radiation in the spectral range 980-1025 $\AA$, where the radiation absorption by nitrogen $N_{2}$ can be omitted. The wavelength of $1025 \AA$ is the natural threshold for the molecular oxygen photoionization reaction. Below $980 \AA$, the radiation is strongly absorbed by nitrogen providing insignificant contribution to the production of photoelectrons. Taking into account the fine structure of the oxygen absorption spectrum, in the integral over the wavelength range 980-1025 $\AA$ in the general expression for the rate of photoionization was calculated and adopted for further computations. 


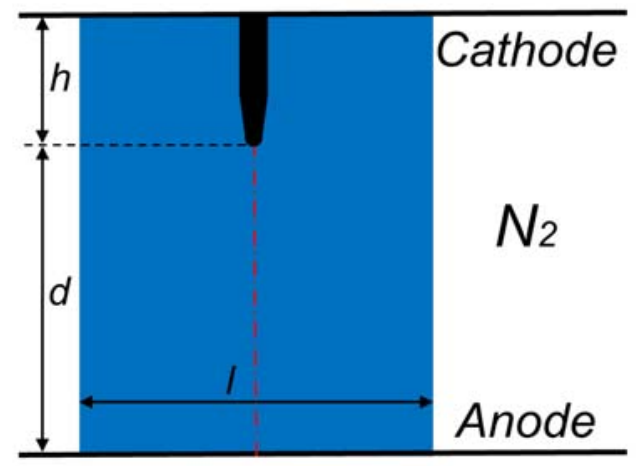

where $n_{e}$ is the electron number density, $n_{\varepsilon}$ is the electron energy density, $t$ is the time variable, and $\boldsymbol{E}$ is the electric field strength. The source coefficients $R_{e}$ and $R_{\varepsilon}$ are defined by

$$
\begin{gathered}
R_{e}=k_{\text {ion }}(\bar{\varepsilon}) n_{n} n_{e}+S_{p h}, \\
R_{\varepsilon}=k_{\text {ion }}(\bar{\varepsilon}) n_{n} n_{e}+k_{\text {diss }}(\bar{\varepsilon}) n_{n} n_{e},
\end{gathered}
$$

where $k_{\text {ion }}(\bar{\varepsilon})$ is the ionization rate as a function on the mean electron energy, $\bar{\varepsilon}=n_{\varepsilon} / n_{e}, n_{n}$ is the total neutral number density, $k_{\text {diss }}(\bar{\varepsilon})$ is the dissociation rate coefficient, and $S_{p h}$ is the photoionization rate. 
The ion component is described by

$$
\frac{\partial n_{i}}{\partial t}+\nabla \cdot \Gamma_{i}=R_{e}
$$

where $n_{i}$ is the $N_{2}^{+}$number density.

The electron, the electron energy and the ion density fluxes $\Gamma_{e}, \Gamma_{\varepsilon}$ and $\boldsymbol{\Gamma}_{i}$ respectively, are given by the expressions

$$
\begin{gathered}
\boldsymbol{\Gamma}_{e}=-n_{e} \mu_{e} \boldsymbol{E}-D_{e} \nabla n_{e} \\
\boldsymbol{\Gamma}_{\varepsilon}=-\frac{5}{3} n_{\varepsilon} \mu_{e} \boldsymbol{E}-\frac{5}{3} D_{e} \nabla n_{\varepsilon} \\
\boldsymbol{\Gamma}_{\boldsymbol{i}}=-n_{i} \mu_{i} \boldsymbol{E}-D_{i} \nabla n_{i}
\end{gathered}
$$

where $\mu_{e}$ and $\mu_{i}$ are the electron and ion mobilities, and $D_{e}$ and $D_{i}$ are the electron and ion diffusivities.

The electric field is accounted self-consistently in the model by implementing the Poisson's equation:

$$
\varepsilon_{0} \nabla \cdot \boldsymbol{E}=-q\left(n_{i}-n_{e}\right)
$$

where, $q$ is the elementary charge, and $\varepsilon_{0}$ is the electrical constant.

The photoionization rate $S_{p h}$ is implemented in the "differential" formulation i.e. based on the numerical solution of the Helmholtz equations set (Bourdon et al, 2007).

$$
\nabla^{2} S_{p h}-\Lambda_{p h}^{-2} S_{p h}=-G_{p h} R_{e}
$$

Here, $\Lambda_{p h}$ is the effective photon path length, $G_{p h}$ is the coefficient of the conversion of the ionization rate $R_{e}$ into photon radiation. The percent of oxygen admixture was set to $2 \%$ (15 Torrs in the equivalent partial pressure units).

We use uniform plasma number density not exceeding $10^{3} \mathrm{~cm}^{-3}$ and the zero electric field and the photoionization rate $S_{p h}$ as the initial conditions. The boundary conditions are given in terms of generalized expressions for the particle and the electron energy density fluxes on the solid electrode walls (Kozhevnikov et al, 2015) 


$$
\begin{gathered}
\boldsymbol{\Gamma}_{e} \cdot \boldsymbol{n}=\frac{1}{4} n_{e} \bar{v}_{e}-\gamma\left(\boldsymbol{\Gamma}_{i} \cdot \boldsymbol{n}\right)+\mu_{e} n_{e}(\boldsymbol{E} \cdot \boldsymbol{n}), \\
\boldsymbol{\Gamma}_{\boldsymbol{i}} \cdot \boldsymbol{n}=\frac{1}{4} n_{i} \bar{v}_{i}+\mu_{i} n_{i}(\boldsymbol{E} \cdot \boldsymbol{n}), \\
\boldsymbol{\Gamma}_{\boldsymbol{\varepsilon}} \cdot \boldsymbol{n}=\frac{1}{2} n_{\varepsilon} \bar{v}_{e}-\bar{\varepsilon} \cdot \gamma\left(\boldsymbol{\Gamma}_{\boldsymbol{i}} \cdot \boldsymbol{n}\right),
\end{gathered}
$$

where $\boldsymbol{n}$ is the normal vector to the wall surface, $\bar{v}_{e}$ and $\bar{v}_{i}$ are the electron and ion thermal velocities, respectively, and $\gamma=0.1$ is the secondary electron emission coefficient of the ion-wall interaction in nitrogen.

The simulation also accounts the contribution of the field emission (autoelectronic emission) from the cathode surface due to the increase of an electrostatic field near the emission centers formed by the metallic surface roughness. This electron flux is given in terms of a convenient Fowler-Nordheim expression (Kozyrev et al, 1987).

The complete discharge plasma system of equations (1)-(4) is solved in the COMSOL Multiphysics software with Plasma Module implementing the above two-moment model DC-discharge physics. Prior to this, the ionization rates and the electron mobility were calculated using the BOLSIG+ solver (Hagelaar \& Pitchford, 2005) except the dissociation rate coefficient that was taken from another source (Cosby, 1993).

We compare the simulation results according to two discharge models. In the first one (I), photoionization was not included, while the second model (II) implements all enlisted elementary processes. The following simulation results of the calculations are the refinement of the preliminary computations of a similar discharge type presented in the conference paper (Kozhevnikov et al, 2018). The effects of oxygen molar fraction increasing in nitrogen (more than $2 \%$ ) and gas diode parameters variations on the gas discharge dynamics have not been studied focusing on the configurations close to the experimental one.

\section{Results of the simulation}

The comparison of the voltage - time profiles is shown in Figure 4 (switching characteristics) for both discharge models. We assume the breakdown formation to be a time point having the maximum voltage at the discharge gap.The breakdown occurs at $t_{\text {breakdown }} \approx 92 \mathrm{~ns}$ $\left(U_{\text {breakdown }} \approx 12 \mathrm{kV}\right.$ ) for both simulation regimes (with photoionization and 
without it). The presence of photoionization just slightly reduces the breakdown voltage value by no more than $50 \mathrm{~V}$. Such difference is negligibly small, so we can assume that the switching characteristics of two modes are practically identical.

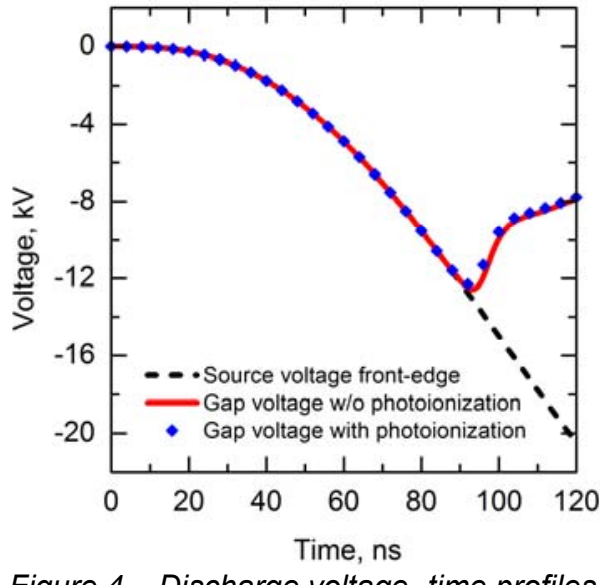

Figure 4 - Discharge voltage- time profiles

Puс. 4 - Коммутационные характеристики разряда

Слика 4- Профрили пражњења напон-време

The discharge evolution is demonstrated in the sequence of the static images in Figure 5. In both cases, the discharge initiation occurs approximately at the time point of $t=50 \mathrm{~ns}$. The movement of the plasma channel begins with the expansion of the initial cathode formation in both spatial directions. After that, approximately from the time point of $t=80 \mathrm{~ns}$, the formation of a plasma tip on the spherical plasma cloud surface occurs. This tip is the main channel of the discharge which slightly expands in the radial direction during the motion. The formation of the initial spherical distribution is associated with the intense losses of the electron energy in the electron impact $\mathrm{N}_{2}$ dissociation reaction. After the electric field exceeds the Lozansky-Firsov criterion threshold value, the rapid ionization wave development starts from the $0.5-1.0 \mathrm{~mm}$ spherical layer surface. The process ends with the discharge gap switching stage at the time point of the gap intersection with the ionization wave channel $(t=90 \mathrm{~ns})$. The gap voltage drop and the corresponding significant increase of the total discharge current accompanies this.

The comparison of calculations with photoionization and without it shows that the effect of the latter on the development of gas discharge is insignificant if the electron impact dissociation reaction of molecular 
nitrogen is included in the model. Also, the quantitative characteristics of the plasma do not change. The significant increase of the oxygen partial pressure in the photoionization model, and hence the fraction of oxygen in gas mixture will probably lead to a visible change in the spatial discharge structure, but also the simulation will require a more accurate plasma-chemical reaction set. Nevertheless, one of this paper's aims is to investigate the influence of a minor electro-negative mixture to the discharge formation and evolution.

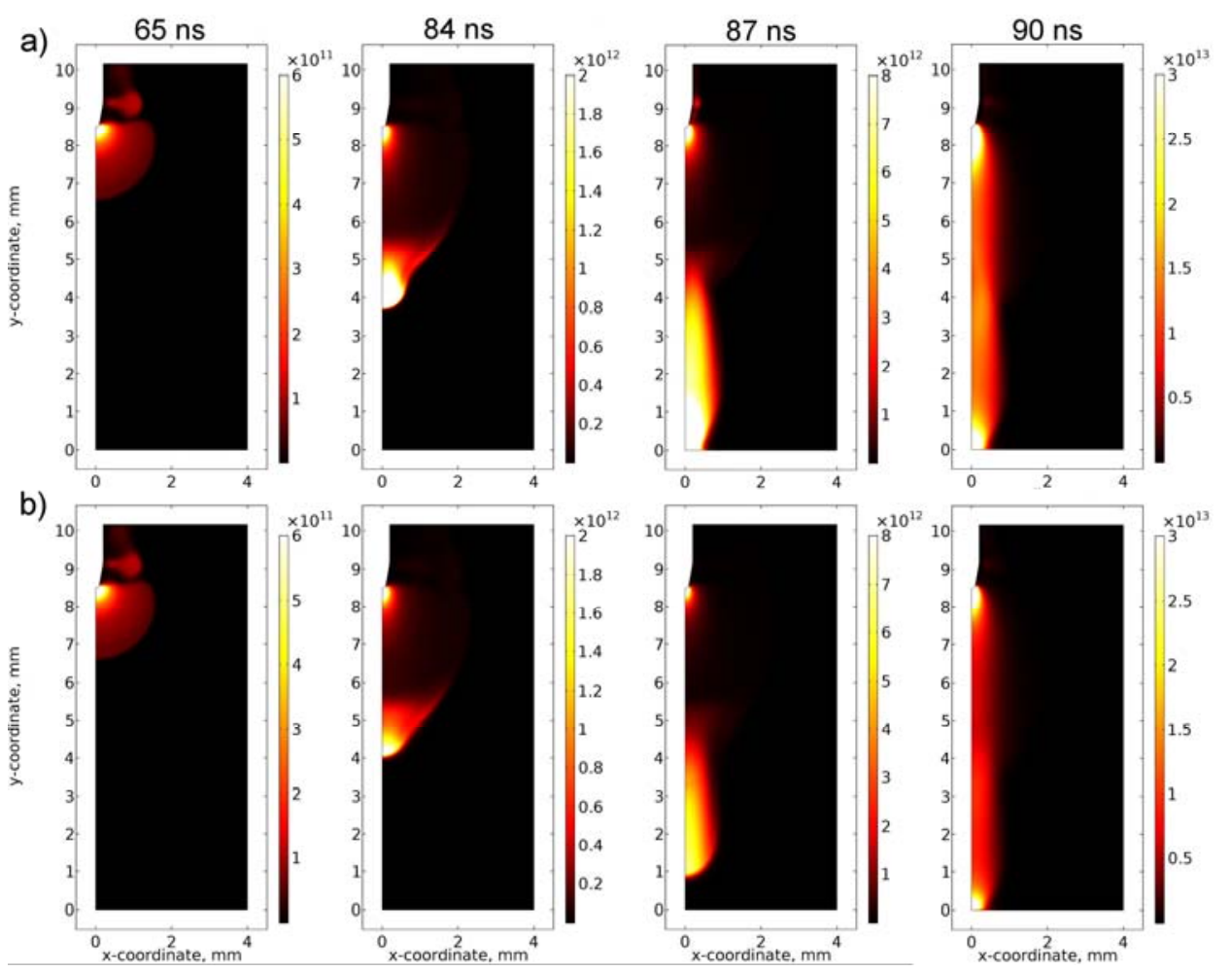

Figure 5 - Spatial distribution of the electron number density (scale in $\mathrm{cm}^{-3}$ ) for gas discharge a) without and b) with the photo-ionization process for the same time points

Puc. 5 - Пространственные распределения концентрации электронов (в единицах в куб.см.) в газовом разряде а) без и b) с учётом процесса фотоионизации в одинаковые моменты времени

Слика 5 - Просторна дистрибуција густине броја електрона (скала у $\mathrm{cm}^{-3}$ ) за пражњење гаса: а) без процеса фротојонизацијеза исте временске тачке и б) са процесом фоотојонизације за исте временске тачке 
Additionally, the parameters of runaway electrons have been calculated in order to discover their influence on the discharge dynamics. The calculations were based on the "hybrid" theoretical approach, involving the principles of physical kinetics described earlier (Kozyrev et al, 2016). The results show that the runaway electron current passing through the anode is too small compared to the full discharge current, so the influence of the runaway electrons on the discharge is negligible. Such conclusions are connected with the long rise time (more than $100 \mathrm{~ns}$ ) of the operating voltage pulse.

\section{Conclusion}

The simulation of the gas-filled diode breakdown in the tip-to-plane electrodes configuration shows good agreement with the existing experimental data. The current theoretical study shows that gas photoionization insignificantly affects the discharge spatial structure for the positive polarity of the anode voltage. It was also shown that, in gas mixtures containing a valuable amount of nitrogen, the electron impact dissociation plays an important role in the formation of the spatiallyinhomogeneous discharge structure.

Our theoretical study of gas discharges of submicrosecond duration substantially complements the existing experimental base. The obtained information about the time-spatial discharge structure allows studying the generation of runaway electrons and X-rays under the atmospheric pressure. This opens up broad prospects for the creation of high voltage power supplies for UV and VUV excilamps as well as for the application in the fields of industrial $X$-ray radiography.

\section{References}

Akishev, Y., Goossens, O., Callebaut, T., Leys, C., Napartovich, A., \& Trushkin, N. 2001. The influence of electrode geometry and gas flow on coronato-glow and glow-to-spark threshold currents in air. Journal of Physics $D$ : Applied Physics, 34(18), pp.2875-2882. Available at: https://doi.org/10.1088/0022-3727/34/18/322.

Bourdon, A., Pasko, V.P., Célestin, S., Liu, N.Y., Ségur, P., \& Marode, E. 2007. Efficient models for photoionization produced by non-thermal gas discharges in air based on radiative transfer and the Helmholtz equations. Plasma Sources Science and Technology, 16(3), pp.656-678. Available at: https://doi.org/10.1088/0963-0252/16/3/026 
Cosby, P.C. 1993. Electron-impact dissociation of nitrogen. The Journal of Chemical Physics, 98(12), pp.9544-9553. Available at: https://doi.org/10.1063/1.464385.

Eichwald, O., Yousfi, M., Ducasse, O., Merbahi, N., Sarrette, J.P., Meziane, M., \& Benhenni, M. 2011. Electro-Hydrodynamics of Micro-Discharges in Gases at Atmospheric Pressure. In H.E. Schulz Ed., Hydrodynamics - Advanced Topics.IntechOpen. Available at: https://doi.org/10.5772/28929.

Gogolides, E., \& Sawin, H.H. 1992. Continuum modeling of radio-frequency glow discharges. I. Theory and results for electropositive and electronegative gases. Journal of Applied Physics, 72(9), pp.3971-3987. Available at: https://doi.org/10.1063/1.352250.

Hagelaar, G.J.M., \& Pitchford, L.C. 2005. Solving the Boltzmann equation to obtain electron transport coefficients and rate coefficients for fluid models. Plasma Sources Science and Technology, 14(4), pp.722-733. Available at: https://doi.org/10.1088/0963-0252/14/4/011.

Kozhevnikov, V.Y., Kozyrev, A.V., Batrakov, A.V., Semeniuk, N.S., \& Karaban, V.M. 2015. Diagnostics of primary arcing in electronics of satellite telecommunication systems. In 2015 23rd Telecommunications Forum Telfor (TELFOR).Institute of Electrical and Electronics Engineers (IEEE), pp.615-618. Available at: https://doi.org/10.1109/telfor.2015.7377542.

Kozhevnikov, V.Y., Kozyrev, A.V., Semeniuk, N.S., \& Kokovin, A.O. 2018. Theoretical Simulation of Nanosecond High Pressure Gas Discharge in the Pinto-Plate Gap.In 2018 26th Telecommunications Forum (TELFOR).Institute of Electrical and Electronics Engineers (IEEE), pp.1-4. Available at: https://doi.org/10.1109/telfor.2018.8611902.

Kozyrev, A.V. et al. 1987. Autoemission processes and Transition from the glow-discharge to Arc-discharge. Zhurnal Tekhnicheskoi Fiziki, 51(1), pp.58-64.

Kozyrev, A., Kozhevnikov, V., Lomaev, M., Sorokin, D., Semeniuk, N., \& Tarasenko, V. 2016. Theoretical simulation of the picosecond runaway-electron beam in coaxial diode filled with SF 6 at atmospheric pressure. EPL (Europhysics Letters), 114(4), p.45001. Available at: https://doi.org/10.1209/0295-5075/114/45001.

Kulikovsky, A.A. 1999. Two-dimensional simulation of the positive streamer in $\mathrm{N} 2$ between parallel-plate electrodes. Journal of Physics D: Applied Physics, 28(12), pp.2483-2493. Available at: https://doi.org/10.1088/0022$3727 / 28 / 12 / 015$.

Schaefer, G., Kristiansen, M., \& Guenther, A. 1990. Gas Discharge Closing Switches. Available at: https://doi.org/10.1007/978-1-4899-2130-7.

Shao, T., Tarasenko, V.F., Zhang, C., Baksht, E.K., Zhang, D., Erofeev, M.V., Ren, C., Shutko, Y.V., \& Yan, P. 2013. Diffuse discharge produced by repetitive nanosecond pulses in open air, nitrogen, and helium. Journal of Applied Physics, 113(9), p.93301. Available at: https://doi.org/10.1063/1.4794031. 

ПЛОСКОГО ЭЛЕКТРОДА

Василий Ю. Кожевников ${ }^{\mathrm{a}}$, Андрей В. Козырев ${ }^{\mathrm{a}}$, Александр О. Коковин ${ }^{\text {, }}$ Владислав С. Игумнов

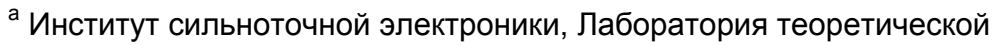
физики, г. Томск, Российская Федерация

б Томский политехнический университет, Лаборатория номер 46

г. Томск, Российская Федерация

РУБРИКА ГРНТИ: 29.27.00 Физика плазмы

ВИД СТАТЬИ: оригинальная научная статья

ЯЗЫК СТАТЬИ: английский

Резюме:

В данной работе рассматриваются результаты численного моделирования быстрого разряда при атмосфрерном давлении в сильно неоднородной конфигурации диода «острие-плоскость», заполненного смесью азота и кислорода. Моделирование основано на современной гидродинамической модели разрядной плазмы, учитывающей также фотоионизацию газа. Было показано, что при отсутствии фотоионизации разряд развивается аналогично случаю с фотоионизацией (за исключением случая обратной полярности приложенного напряжения). Теоретические результаты соответствуют существующим экспериментальным данным для структуры пространственного разряда и для временных характеристик тока / напряжения разряда.

Ключевые слова: плазма, численное моделирование, атмосферные разряды.

ПРАЖЊЕЊЕ У НАНОСЕКУНДАМА ПРИ АТМОСФЕРСКОМ ПРИТИСКУ ОД НЕУНИФОРМНЕ ЕЛЕКТРОДЕ (ВРХ) ПРЕМА РАВНОЈ ЕЛЕКТРОДИ

Василиј Ј. Кожевников ${ }^{a}$, Андреј В. Козирев ${ }^{a}$, Александар О. Коковин ${ }^{\text {, }}$ Владислав С. Игумнов ${ }^{6}$

а Институт високе струје, Лабораторија за теоријску фризику,

Томск, Руска Федерација

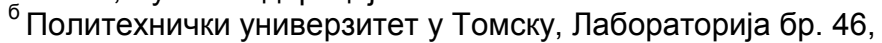

Томск, Руска Федерација

ОБЛАСТ: фризика плазме

ВРСТА ЧЛАНКА: оригинални научни рад

ЈЕЗИК ЧЛАНКА: енглески 


\section{Сажетак:}

У раду се разматрају резултати нумеричке симулације брзог пражњења при атмосфрерском притиску у високо нехомогеној конфригурацији диоде типа врх-раван напуњене смешом азота и кисеоника. Симулација се заснива на савременом хидродинамичком моделу пражњења плазме, који такође узима у обзир фоттојонизацију гаса. Показано је да се, у одсуству фотојонизујућег пражњења, он развија слично као и код фотојонизације, са изузетком напона инверзне поларизације. Теоријски резултати су конзистентни са постојећим експерименталним подацима за просторну структуру пражњења и за карактеристике пражњења напона/струје.

Кључне речи: плазма, нумеричка симулација, атмосферска пражњења.

Paper received on / Дата получения работы / Датум пријема чланка: 02.03.2019. Manuscript corrections submitted on / Дата получения исправленной версии работы / Датум достављања исправки рукописа: 12.05.2019.

Paper accepted for publishing on / Дата окончательного согласования работы / Датум коначног прихватања чланка за објављивање: 14.05 .2019$.

(c) 2019 The Authors. Published by Vojnotehnički glasnik / Military Technical Courier (www.vtg.mod.gov.rs, втг.мо.упр.срб). This article is an open access article distributed under the terms and conditions of the Creative Commons Attribution license (http://creativecommons.org/licenses/by/3.0/rs/).

() 2019 Авторы. Опубликовано в «Военно-технический вестник / Vojnotehnički glasnik / Military Technical Courier» (www.vtg.mod.gov.rs, втг.мо.упр.срб). Данная статья в открытом доступе и распространяется в соответствии с лицензией «Creative Commons» (http://creativecommons.org/licenses/by/3.0/rs/).

() 2019 Аутори. Објавио Војнотехнички гласник / Vojnotehnički glasnik / Military Technical Courier (www.vtg.mod.gov.rs, втг.мо.упр.срб). Ово је чланак отвореног приступа и дистрибуира се у складу са Creative Commons лиценцом (http://creativecommons.org/licenses/by/3.0/rs/).

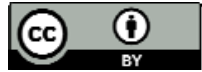

